\title{
Leadership in a Time of Peril?
}

\section{The Private Junior College President}

\author{
Adam Morris, Ed.D. \\ Assistant Director, Operations Management \\ College of Engineering \\ University of Arkansas, Fayetteville, AR 72701 \\ Michael T. Miller, Ed.D. \\ Associate Dean and Professor of Higher Education \\ College of Education and Health Professions \\ University of Arkansas, Fayetteville, AR 72701
}

Received: Dec. 11, 2012 Accepted: January 14, 2013 Published: February 1, 2013

doi:10.5296/jse.v3i1.2830

URL: http://dx.doi.org/10.5296/jse.v3i1.2830

\begin{abstract}
The number of private junior colleges has decreased steadily over the pasit four decades, and with fewer private institutions operating, access for many students has similarly decreased. Private junior colleges differ in many ways from their public community college peers, yet they often serve a very distinct audience, namely those interested in transfer-related coursework and degree programs. As the number of institutions has decreased, presidential leadership has become increasingly important to steward these institutions into the future. The current study explored the roles, challenges, and future issues for private junior colleges.
\end{abstract}

Keywords: Junior colleges, Public community college peers 
Private junior colleges have an important history in the discussion and realm of higher education. These institutions serve a unique function by providing access to higher education to students who might otherwise not choose to pursue any postsecondary education. Unlike their public community college counterparts, these institutions often focus scholarship aid with individual attention to bring students to campus, and, they often serve a segment of the student population accustomed to private institution enrollment, that is, students who have attended private secondary schools and due to either ability or performance, would not continue with an education unless a nurturing, small, private environment were available to bring them into postsecondary education. Nearly 75 years ago there were purported to be over 350 private junior colleges, many sponsored by churches or religious orders, but due to financial constraints, the rise of public community colleges, and a host of other reasons, the number is now close to 1institutions (Williams, 1989; Morris, Modica, \& Miller, 2010).

Williams (1989) argued that private junior colleges, to succeed, must market their strengths, increase their enrollments, be efficient in their fiscal management, and maintain strong leadership. Morris, Modica, and Miller (2010) explored how private junior colleges use and offer athletic programs, finding that nearly half of all private junior colleges offered comprehensive sport programs. As a prequel to the athletic study, the current study was designed to explore and describe the leadership of private junior colleges and to present more baseline data on the current status of private junior colleges.

\section{Overview of Private Junior Colleges}

Little literature exists on the private junior college. Williams' (1989) summary of these institutions was not optimistic, even framing the title to indicate that they were within a framework of fighting for their very survival. Cohen and Brawer (2008) indicated that these institutions had passed their prime, and that nearly half of them had closed since the late-1980s. Yet, they also wrote with no particular validation that "although the independent nonprofit junior colleges passed their prime decades ago, they will not disappear" (p. 450).

Private junior colleges were among the first to be established, and in the early 1920's, two-thirds of all junior/community colleges were private (137 of 207; Cohen \& Brawer, 2008). These colleges were typically religiously affiliated, and the majority of them were located in the southern United States. Cohen and Brawer noted that in 1947-48, half of all junior colleges in the country were private, and that this population of 322 colleges was the highest number ever operated. The number of private colleges operating has decreased consistently since 1947-48, dropping to 112 in 2004-2005. The Morris et al (2010) study used the Carnegie Foundation for the Advancement of Teaching (2006) to identify private junior colleges, and developed a listing of 116 institutions. After removing proprietary institutions from the listing, they developed a population of 47 institutions.

Morris' study suggested that private junior colleges utilize a variety of strategies to maintain enrollment, and his research focused on the use of athletics. He found that approximately half of the institutions in his study offered inter-institutional competitive teams, namely basketball (17 of 22 institutions offered men's basketball and 14 of them offered women's basketball). Although his study identified no significant difference in terms of enrollment size based on 
sports offerings, he did find that those private junior colleges that offered sports for their students enrolled approximately 50 more students each year. Marketing the benefits and opportunities present in private junior colleges has been noted as vital to their success (Mitchell, 1990), and other options to enhance enrollment undertaken by private four-year colleges may also apply, such as the addition of online programs to working adults (Morris \& Miller, 2008). Yet, often the higher tuition required to attend a private two-year college can prove to be a significant obstacle to enrollment (Mupinga, Wagner, \& Wilcosz, 2009).

Although there is little academic or practitioner-oriented discussion of the private junior college, there has been a significant scholarly discourse on the nature of academic leadership. Academic leadership has been noted as the catalyst for institutional survival, growth, success, and failure (Sibley, 1998). This notion that academic administration has a significant influence on the success or failure of a college has been traced to even the early 1900s when "administration" became a more common fixture on collegiate campuses with presidents hand-selecting faculty members and determining who would be allowed to teach, and to teach different categories of students (Veysey, 1965).

As academic leadership has grown and evolved over the past century, academic leadership has been studied in a variety of contexts and has referenced the need to understand the role orientation of leaders and how they envision the challenges confronting them. Seagren, Wheeler, Creswell, Miller, and Van Horn-Grassmeyer (1994) conducted a national study of community college leaders and found that role orientation was vital to how these individuals approached their job, their level of investment in creating change, and their beliefs about the role and function of their academic units. Although now nearly 20 years old, the findings of this national study funded by the National Community College Chair Academy, reflect the importance of academic leaders in crafting and sustaining a viable future for their institutions. The current study was developed around this concept, and places tremendous importance and value on the leadership of an institution for its survival and livelihood.

\section{Research Procedures}

The research-team developed survey instrument was an adaptation, with permission, of the Seagren et al (1994) work. Following a brief descriptive section, the survey included 12 roles and 34 challenges, each of which the private junior colleges were asked to rate their perceptions on. For the 12 roles, the study participants were asked to rate how they perceived their role as president, using a five-point Likert-type scale where 5=Very Important progressing to $1=$ Not Important. Similarly, presidents were asked to what extent they agreed that they would face the identified challenges at their institutions during the next five years, using the same five-point Likert-type scale. The survey was converted to an electronic format and distributed to private junior college presidents in the spring and summer terms of 2011.

The sample consisted of the 47 private junior colleges identified by the Carnegie Foundation for the Advancement of Teaching (2006) as meeting the criteria of being private not-for-profit institutions and offering associate degrees and/or 2-year programs. The Carnegie Foundation initially identified 116 institutions as meeting these criteria, but upon review of the institutions, all that were specialized training institutions were removed from 
the population (such as barber colleges, cosmetology schools, etc). This resulted in 51 institutions meeting the criteria used in the study for private junior colleges. The internet was used to verify the inclusion of each institution, and four additional institutions were deleted from the study, as they were vocationally specialized institutions.

Once each institution was identified, an internet search was completed to find the name and email address of the institution's president. The internet-identified individual was then included in the sample and received the electronic survey. An initial email was sent to each sample participant indicating the upcoming survey, followed by the actual survey, and for non-respondents, two follow up electronic communications with a link to the survey. Ultimately, 18 responses were returned, with one individual declining participation in the study, and a total yield of 17 usable responses (36\% response rate). Considering the exploratory nature of the study, this response rate was accepted, acknowledging that the low response rate may indicate that not all findings are truly generalizable to the entire population of private junior college presidents.

\section{Findings}

Institutional Description: As shown in Table 1, 88\% of the responding private junior colleges were sponsored by a religious organization, such as a religious denomination or local church parish. These institutions offered an average of 22 degree programs, with a range of offerings from four to 49 different programs of study. The institutions made use of on average 29 full-time faculty members and 35 part-time or adjunct faculty, and they enrolled on average, 469 students, with a range of the smallest responding institution enrolling 130 students and the largest enrolling 1,100 students.

Roles: Of the 12 roles adapted from the Seagren et al study, seven were rated in the Important (4) to Very Important (5) by the presidents and the other five were rated in the Undecided (3) to Important (4) range. These ratings were based on how current presidents perceived the importance of each of these roles on their current practice leading their institutions. The overall mean rating for the roles was 4.08 (with a range of 3.70 to 4.78), with the greatest importance placed on Entrepreneurial, Planning, Caretaking, and Advocating roles (see Table 2). The least importance was placed on Information Dissemination, Motivation, and Evaluation.

Challenges: Responding presidents rated the extent of their agreement levels that the challenges identified on the survey were important to them. The 34-challenges on the survey were adapted from Seagren et. al's work, where the challenges were identified and rated by public community college academic leaders. The 34-items had an overall mean agreement level of 4.14 (on a 5-point, Likert-type scale), where the higher number represents stronger agreement levels that the item is a challenge for the respondent as a private junior college president. Nine challenges were rated between 4.50 and 5.00, with the strongest agreement with the challenges of obtaining financial resources (mean 4.89; SD .5299), maintaining the physical plant (mean 4.88; SD .6200), and attracting new student populations (mean 4.81; SD .7009). As shown in Table 3, these nine challenges were followed by 14 in the 4.00 to 
4.50 range, 10 between 3.50 and 3.99, and one challenges was rated under 3.50 (encouraging more technical preparation in high schools mean 3.28; SD .7283).

Future Issues: Responding presidents were asked to identify up to five future challenges facing their colleges using an open-ended response. Responding presidents identified 88 possible challenges that they perceived would impact their institutions, and, as shown in Table 4, 14 of the 17 presidents (82\%) indicated that student recruitment, institutional financial stability (12/17; 70\%), and capital maintenance (10/17; 58\%) were serious pressing challenges. As a note, presidents used a variety of terms and phrases, and Table 4 includes these items as a thematic category. For example, presidents indicated challenges such as "we need more students," "increasing enrollment is challenge \#1," and "improving enrollment" were all classified as student recruitment. The challenges that were identified the least for presidents were succession planning, external contract management, and athletic program continuation, all of which were identified by only one president each.

\section{Discussion}

Private junior colleges seem to be on the verge of extinction, yet, they consistently find a way to survive. The biggest challenges these presidents identified was related to their financing, of which increasing enrollment appeared to be an obvious strategy for raising revenue. Perhaps the greatest challenge they may find in this fight for students can actually be traced to state legislative behaviors, and as state funding for public four year institutions and even public community colleges has remained stable, lost ground to inflation, or even been cut, they are more aggressive in competing with private institutions for students. Many public community colleges, for example, have developed and maintain athletic programs and residence halls, increasing their capacity to directly compete with private junior colleges.

The long-term challenge for private junior colleges is something more than immediate survival, but how they are able to define and enhance their niche markets in a manner that can support the physical plant and labor necessary to offer a strong academic experience. The identification of this 'niche' market will be predicated on strong presidential leadership that can collaborate effectively with a governing board to identify what the future can look like. And, as these colleges must rely on strong leaders, their boards must be willing to invest in finding a new generation of pioneers to lead these colleges through this century. This idea is reinforced by the strong identification of the need to serve the role of entrepreneur.

To better study these private junior college presidents, in-depth interviews and case study research may prove helpful in finding what is working, and what can work at multiple institutions to create a new future. The Seagren et al (1994) challenges used in the present study were a convenient and strong starting point for the discussion of academic leadership, but they were perhaps dated and might not have been particularly well suited for private junior colleges. Many of the challenges, for example, focused on the emergence and frustration with technology and how technology was in the process of transforming higher education - a transition that has already taken place since the Seagren study. This is especially true with online/distance courses and implementing all the technology needs associated with online learning. (Anderson, 2008). Similarly, issues related to specific job training and 
serving at-risk students might not have been appropriate for the population of private (non-profit) junior colleges; however, until a more detailed profile of private junior colleges is developed, this type of exploratory study will be necessary to detail these college's activities and audiences.

Another element that must be considered in the discussion of private junior colleges is the role of religious oversight and affiliation. To some extent, these colleges might be appropriately tied to access-related concepts, almost missionary work, providing education to at-risk students in urban environments and providing a high level of personal interaction that helps them rise above poverty. A high-tuition, high-aid policy might not be effective in such an environment, but building and articulating on a religious foundation might also prove to be an asset if institutions can transcend local synods, parishes, or geographic boundaries.

From an optimistic perspective, these junior colleges have survived in some cases nearly 150 years, and with a religious congregation behind them, they may have built-in constituent groups to support their work through financial donations and contributed expertise. To optimize this potential, college presidents will need to rely on both accurate and comprehensive training for an uncertain future. Associations such as the American Association of Community Colleges, the American Council on Education, and even the National Community College Chair Academy might find both a potential market for training and a service to a struggling segment of the two-year college industry.

\section{References}

Anderson, T.J. (2008). Conquering the fear of online: Advising students to successful online course taking. Distance Learning, 5(4).

Carnegie Foundation for the Advancement of Teaching. (2006, February). 2005 Basic Classification of institutions of Higher Education. Retrieved August 31, 2008, from http://www.carnegiefoundation.org/classification.asp?key=791

Cohen, A. M., \& Brawer, F. B. (2008). The American community college (5th ed.). San Francisco: Jossey-Bass.

Gmelch, W. H., Wolverton, M., Wolverton, M. L., \& Sarros, J. C. (1999). The academic dean: An imperiled species searching for balance. Research in Higher Education, 40, 717-740.

Mitchell, P. T. (1990). Professional approach to marketing the private junior college. In R. H. Woodroof (Ed.), The viability of the private junior college, New Directions for Community Colleges, No. 69 (pp. 19-32). San Francisco: Jossey-Bass.

Morris, A., \& Miller, M.T. (2008). Profile of online programs in private colleges: From collegeto university with a click. Journal of Academic Leadership, 6(1), available online at www.academicleadership.org/

Morris, A., Modica, J., \& Miller, M. T. (2010). Athletic offerings in private junior colleges. Community College Enterprise, 16(1), 75-88 


\section{Macrothink}

Journal of Studies in Education

ISSN 2162-6952 2013, Vol. 3, No. 1

Mupinga, D., Wagner, K., \& Wilcosz, R. (2009). Choosing between public and private two-year postsecondary technical institutions. Clearing House, 82(5), 233-236.

Sibley, W. A. (1998). University management 2010, challenging choices and difficult decisions. Stillwater, OK: New Forums Press.

Seagren, A. T., Wheeler, D. W., Creswell, J. W., Miller, M. T., \& Van Horn-Grassmeyer, K. (1994). Academic leadership in community colleges. Lincoln, NE: University of Nebraska Press.

Veysey, L. R. (1965). The emergence of the American university. Chicago: University of Chicago.

Williams, D. N. (1989, December). The survival of the private junior colleges. ERIC Clearinghouse for Junior Colleges. 
Table 1. Institutional Description

\begin{tabular}{lll}
\hline Characteristic & Number & $\%$ \\
\hline Institutional Classification & & \\
$\quad$ Sponsored by religion & 15 & $88 \%$ \\
$\quad$ Sponsored by independent non-profit & 2 & 22 \\
& & \\
Number of degree programs & 22 & \\
$\quad$ Range & $4-49$ & \\
& & \\
Average Number of Faculty & & \\
$\quad$ Full-time & 29 \\
$\quad$ Range & $19-60$ \\
$\quad$ Part-time/adjunct & 35 & \\
Range & $2-76$ \\
& \\
Enrollment & \\
Average & 469 \\
$\quad$ Range & $130-1,100$ \\
\hline
\end{tabular}

Table 2. Managerial Roles of Private Junior College Presidents

\begin{tabular}{lll}
\hline Role & Mean & SD \\
\hline Entrepreneur & 4.78 & 1.001 \\
Planner & 4.28 & 1.028 \\
Caretaker & 4.25 & 1.380 \\
Advocator & 4.23 & .4897 \\
Visionary & 4.17 & .9910 \\
Negotiator & 4.12 & .7480 \\
Mentor & 4.01 & 1.118 \\
Delegator & 3.99 & .6897 \\
Resource Allocator & 3.89 & .8746 \\
Information Disseminator & 3.81 & 1.540 \\
Motivator & 3.76 & 1.232 \\
Evaluator & 3.70 & .8208 \\
\hline
\end{tabular}


Table 3. Challenges Facing Private Junior College Presidents

\begin{tabular}{|c|c|c|}
\hline Challenge & Mean & SD \\
\hline Obtaining financial resources. & 4.89 & .5299 \\
\hline Maintaining the physical plant. & 4.88 & .6200 \\
\hline Attracting new student populations. & 4.81 & .7009 \\
\hline Offering courses through distance education. & 4.57 & .6892 \\
\hline Increasing emphasis on the transfer program. & 4.57 & .9102 \\
\hline Maintaining program quality. & 4.56 & 1.0011 \\
\hline Strengthening the curriculum. & 4.55 & .8972 \\
\hline Increasing use of technology campus. & 4.55 & .4298 \\
\hline Changing curriculum in response to technology. & 4.51 & 1.0283 \\
\hline Securing and maintaining state of the art technology. & 4.44 & 8998 \\
\hline Increasing influence and impact of accrediting bodies. & 4.39 & .9981 \\
\hline Maintaining high quality faculty. & 4.37 & .7821 \\
\hline Identifying future leaders from among the faculty. & 4.35 & .9928 \\
\hline Responding to the needs of a wider range of students. & 4.30 & .7492 \\
\hline Utilizing more faculty development techniques. & 4.30 & 1.000 \\
\hline Addressing accountability issues. & 4.25 & .8820 \\
\hline $\begin{array}{l}\text { Reallocating monies to programs because of financial } \\
\text { constraints. }\end{array}$ & 4.22 & .7785 \\
\hline Accommodating cultural diversity. & 4.17 & 1.632 \\
\hline Keeping pace with the increasing cost of technology. & 4.12 & 1.3026 \\
\hline Providing leadership training for faculty and chairs. & 4.06 & .8271 \\
\hline Promoting greater gender equity. & 4.01 & 1.846 \\
\hline Developing efficient advisory and registration systems. & 4.00 & 1.2020 \\
\hline Employing new teaching techniques. & 4.00 & 1.0001 \\
\hline Internationalizing the curriculum. & 3.99 & 1.1027 \\
\hline Addressing issues of training for senior faculty. & 3.89 & .7219 \\
\hline Increasing general education requirements. & 3.76 & .9873 \\
\hline Serving at-risk students. & 3.75 & .9901 \\
\hline Decreasing growth in transfer programs. & 3.75 & 1.198 \\
\hline Using quality management techniques. & 3.67 & .8894 \\
\hline $\begin{array}{l}\text { Increasing the use of business and industry advisory } \\
\text { committees. }\end{array}$ & 3.61 & 1.3290 \\
\hline Adapting to tele-community students. & 3.51 & 1.9982 \\
\hline Increasing human relations training. & 3.50 & 1.2358 \\
\hline Adapting to tele-commuting faculty. & 3.50 & .7892 \\
\hline Encouraging more technical preparation in high schools. & 3.28 & .7283 \\
\hline
\end{tabular}


Table 4. Future Issues Facing Private Junior Colleges

\begin{tabular}{ll}
\hline Future Issues & Frequency Identified \\
\hline Student recruitment & 14 \\
Financial stability & 12 \\
Capital maintenance & 10 \\
Academic quality & 9 \\
Online offerings & 9 \\
Faculty recruitment & 7 \\
Enrollment management & 7 \\
Institutional relevance & 5 \\
Endowment management & 5 \\
Grant writing & 3 \\
Faculty rights/tenure & 2 \\
Technology improvements & 2 \\
Leadership succession planning & 1 \\
External contract management & 1 \\
Athletic continuation & 1 \\
\hline
\end{tabular}

